ఠ

CORRIGENDUM

\title{
Fixed combination of lercanidipine and enalapril in the management of hypertension; focus on patient preference and adherence [Corrigendum]
}

\author{
Borghi C, Santi F. \\ Patient Preference and Adherence. 2012;6:449-455. \\ On page 452, Table 1: Effect of fixed association of enalapril- \\ lercanidipine on blood pressure control. \\ The Intervention column data for the 5 th reference $\left(\right.$ Rump $\left.^{61}\right)$ \\ was incorrectly listed as: Enalapril $10 \mathrm{mg}+$ lercanidipine \\ $10 \mathrm{mg}$ or enalapril $10 \mathrm{mg}$ + lercanidipine $20 \mathrm{mg}$. \\ The corrected data is: \\ Enalapril $10 \mathrm{mg}$ + lercanidipine $10 \mathrm{mg}$ or enalapril $20 \mathrm{mg}+$ \\ lercanidipine $10 \mathrm{mg}$.
}

Patient Preference and Adherence is an international, peer-reviewed, open access journal focusing on the growing importance of patient preference and adherence throughout the therapeutic continuum. Patient satisfaction, acceptability, quality of life, compliance, persistence and their role in developing new therapeutic modalities and compounds to optimize clinical outcomes for existing disease states are major areas of interest. This journal has been accepted for indexing on PubMed Central. The manuscript management system is completely online and includes a very quick and fair peer-review system. Visit http://www.dovepress.com/ testimonials.php to read real quotes from published authors. 